\title{
Endrede grenseflater i en norsk religionsmodell?
}

\author{
ULLA SCHMIDT
}

ENGLISH ABSTRACT: In this article I analyse three types of borders in the Norwegian model of religion, as they are expressed in two areas: in the area of constitution and other basic legislation, and in the area of public health care and hospitals. These three types are: 1) the border between the state and the majority church with respect to which I particularly focus on the implications of the recent changes to the Norwegian constitution; 2) between the state and religious and worldview communities; 3) and between the majority church and religious communities. A main conclusion is that these borders follow different patterns and trajectories in the two areas of legislation and health care. In the final section, I discuss this conclusion in the light of Linda Woodhead's recent contributions to a theory of public religion.

NORSK RESUMÉ: Denne artikkelen analyserer tre grenseflater $i$ en norsk religionsmodell, slik disse viser seg på to områder, nemlig $i$ Grunnloven og annen sentral lovgivning, og innen helsesektoren og offentlige sykehus. Disse tre er grenseflatene mellom staten og majoritetskirken, med særlig vekt på betydningen av grunnlovsendringene fra 2012, mellom staten og tros- og livssynssamfunnene, og mellom majoritetskirken og tros- og livssynssamfunnene. En sentral konklusjon er at disse grenseflatene ikke følger de samme linjene når vi sammenligner Grunnloven og annen lovgivning med helsesektor og sykehus, men snarere viser forskjellige mønstre. I et avsluttende avsnitt diskuteres denne konklusjonen nærmere i lys av Linda Woodheads bidrag til teori om offentlig religion.

KEYWORDS: State and religion; constitution and religion; religion in hospitals; Norwegian model of religion 


\section{Grunnlovsendringer, religionsmodell og grenseflater}

I mai 2012, to år før den norske Grunnlovens 200-års-jubileum, ble dens bestemmelser om forholdet mellom stat og religion for første gang gjennomgripende endret. Hva betyr dette for en norsk religionsmodell? Religionsmodellen vil si de former og rammer som religionssystemet i Norge utfolder seg under (Christoffersen, Iversen, Kærgård \& Warburg 2012, 14). I denne artikkelen er jeg særlig opptatt av hva som skjer med grenseflatene i religionsmodellen ved disse endringene, og spesielt grenseflatene slik de arter seg der religion og stat er i berøring. Dermed er det særlig tre typer grenseflater som er aktuelle: mellom staten og majoritetsreligionen, det vil si Den norske kirke, mellom staten og de andre tros- og livssynssamfunnene, og mellom Den norske kirke og tros- og livssynssamfunnene innbyrdes. Blir disse grenseflatene svakere eller tydeligere? Legges de langs andre linjer eller videreføres de på samme måte som tidligere? I andre del av artikkelen vil jeg også se på hvordan disse grenseflatene og måten de endrer seg på kan vise seg konkret, ved å undersøke religion og religionsutøvelse i statlige sykehus.

Religionsmodell kan ifølge Christoffersen, Iversen, Kærgård \& Warburg defineres som "det institusjonalisede og historisk betingede aftryk, som religionssystemets udvikling og interaktion med staten og samfundet gennem historien har efterladt os med" $(2012,14)$. Innen forskning om religion og samfunn er begrepet modell typisk blitt brukt om ulike hovedtyper av forhold mellom stat og kirke, enten som den eller de dominerende religion(ene), eller som forholdet til religion mer generelt (Doe 2011, 2).

Nyere analyser mener å kunne påvise endringstendenser i slike stat-kirkerelasjoner som også er relevante når vi skal se på religionsmodellens grenseflater og hvordan de endrer seg. Basert på et omfattende materiale fra Jonathan Fox's store internasjonale komparative studie av stat- kirke-relasjoner (Fox 2008) argumenterer Benyamin Neuberger for en overordnet endringstendens ved at ulike stat-kirkemodeller ser ut til å konvergere i retning av samarbeid mellom stat og kirke. Både i demokratier med tradisjonelle statskirke-/establishment-modeller, og med sekularitetsmodeller ser det i økende grad ut til at staten på ulike måter samarbeider med religiøse aktører gjennom ulike avtaler og ordninger (Neuberger 2012, 22-23). Establishment-modellen, som Norge sammen med de øvrige nordiske landene og England gjerne er blitt rubrisert under, mener Neuberger beveger seg bort fra 'eksklusivt establishment', der staten har en særlig relasjon til og privilegerer én kirke og religion. Istedet nærmer den seg det han kaller 'økumenisk establishment', der staten i stedet relaterer til flere tros- og livssynssamfunn mer på like fot. En annen side ved denne utviklingen er at staten i mindre grad intervenerer i og styrer religion, og i større grad støtter opp om religion og religiøs virksomhet.

Andre analyser peker med visse nyanser i samme retning. Silvio Ferrari argumenterer for en tendens i de nordiske landene i retning av større selvstendiggjøring av majoritetskirkene, de tidligere statskirkene, fra staten (Ferrari 2010). Han 
ser dette ikke som et utslag av sekulariseringsprosesser, men av at også de nordiske samfunnene går fra religiøs homogenitet til heterogenitet, og at statskirkeordninger er i utakt med en slik samfunnsutvikling. Men han hevder samtidig at et særtrekk ved denne prosessen i de nordiske landene er at selv om de beveger seg i retning av å oppgi særlige bånd mellom staten og én religion, viderefører de samtidig særskilte bånd mellom nasjonen og én religion (Ferrari 2010, 25).

En tilsvarende tolkning er også fremsatt av blant andre Marie Vejrup Nielsen, også her satt i sammenheng med at staten angivelig blir mindre styrende og mer støttende (Nielsen 2012). Et uttrykk for det er at majoritetskirkene beveger seg fra statsstyrte statskirker til mer selvstendige folkekirker.

Disse analysene innebærer samtidig påstander om hvordan grenseflater formes og endres i måten stat og religion forholder seg til hverandre på. Et generelt trekk er en antakelse om at grenseflaten mellom stat og religion i økende grad bestemmes gjennom statens støtte, og i mindre grad gjennom statens intervenerende styring. Derimot er det litt ulike nyanser når det gjelder grenseflaten mellom majoritetskirkene og de andre trossamfunnene. Neuberger og tilsvarende analyser ser ut til å forutsette at denne gradvis brytes ned og mister betydning fordi staten i økende grad forholder seg likt til majoritetskirken og til øvrige trossamfunn (Neuberger 2012, 24). Andre tolkninger, som Ferraris, modifiserer dette og hevder at det fremdeles er en synlig grenseflate mellom majoritetskirke og trossamfunn, men at denne nå konstrueres på en annen måte: ikke gjennom særlige bånd mellom stat og majoritetskirke, men gjennom særlige bånd mellom nasjon og majoritetskirke. I nordisk sammenheng er det ikke minst bruken av betegnelsen "folkekirke" som signaliserer slike bånd Er disse antakelsene om grenseflater og måten de endrer seg på treffende for en norsk kontekst?

\section{Grunnlovsendringer 2012}

Endringene i den norske Grunnlovens bestemmelser i 2012 kom som resultat av en langvarig debatt om forholdet mellom staten og Den norske kirke. Temaet hadde vært gjenstand for både politisk og kirkelig debatt gjentatte ganger i over hundre år, men hver gang uten at det hadde lyktes å få flertall for endringer av Grunnlovens sentrale bestemmelser om kirke og religion (jf. f.eks. NOU 2006: 2, 25-31). Fra slutten av 1990-tallet og utover 2000-tallet kom spørsmålet igjen på dagsordenen, og både et kirkelig og et politisk, regjeringsoppnevnt utvalg foreslo å endre Grunnloven og gjøre Den norske kirke til en folkekirke løsrevet fra staten og dens myndighet. I 2008 lyktes det å få vedtatt et politisk forlik mellom alle partiene representert på Stortinget. Her forpliktet partiene seg i den kommende stortingsperioden til å gå inn for endringer $i$ forholdet mellom stat og kirke, riktignok mindre vidtrekkende enn de tidligere fremlagte forslagene. Forutsetningen var at Den norske kirke gjennomgikk en demokratireform med tanke på å gi kirkens valgte organer større legitimitet og 
styrke forankringen blant kirkemedlemmene. Etter at denne reformen var gjennomført ble så grunnlovsendringene vedtatt i 2012.

Det er tre hovedelementer i disse endringene av bestemmelsene om forholdet mellom stat og kirke. For det første ble bestemmelsen om 'statens offentlige religion' opphevet. For det andre ble bestemmelsene som definerte og innholdsbestemte staten som kirkestyre opphevet. For det tredje vedtok man en ny religionsparagraf som både omfattet forholdet til Den norske kirke og til tros- og livssynssamfunnene. Denne nye paragrafen lyder i sin helhet:

Alle innbyggere i riket har fri religionsutøvelse. Den norske kirke, en evangeliskluthersk kirke, forblir Norges folkekirke og understøttes som sådan av staten. Nærmere bestemmelser om Kirkens ordning fastsettes ved Lov. Alle tros- og livssynssamfunn skal understøttes på lik linje (Grunnloven § 16).

For å undersøke hva disse endringene betyr for grenseflatene i religionsmodellen er det hensiktsmessig å orientere analysen ut fra de to begrepssettene religionsfrihet og kirkelig autonomi, og religionslikhet og likebehandling. Dette er i utgangspunktet normative begreper hentet fra den menneskerettslige, juridiske og politisk-filosofiske diskursen. Her bruker jeg dem imidlertid som heuristiske begreper for å avdekke og tydeliggjøre eventuelle endringer - og fravær av endringer - i religionsmodellen og dens grenseflater.

\section{Statsreligion og religionsfrihet}

Siden Grunnloven ble vedtatt i 1814 og frem til 2012 har Norge hatt statsreligion, i henhold til bestemmelsen om at "Den evangelisk-lutherske Religion forbliver Statens offentlige Religion" (tidligere Grunnloven § 2). Som begrepet 'forbliver' uttrykker, dreide dette seg ikke om en ny idé, men om en videreføring av reformasjonstidens prinsipp om at rikets enhet forutsatte religiøs enhet, og at fyrsten og folket hadde samme religion. En slik bestemmelse om statsreligion utløser selvsagt flere spørsmål knyttet til religionsfrihet. Hva med friheten til å bekjenne en annen tro enn statens? Og til å danne andre trossamfunn? Og er statens egen religion underlagt statens styring og intervensjon, eller har den også selvstendighet og autonomi?

Religionsfrihet kom inn i den norske Grunnloven i 1964, altså svært sent. I praksis ble det likevel etablert langt tidligere gjennom pragmatisk tolkning av Grunnlovens ordlyd og gjennom underliggende lovverk. Dissenterloven fra 1845 ga borgerne rett til å danne og tilhøre andre kristne kirkesamfunn, og fra 1902 ble det gitt generell adgang til fri religionsutøvelse også for dem som tilhørte andre religioner enn kristendommen. Forbud mot konkrete grupper ble gradvis fjernet fra Grunnloven (mot jøder 1851, munkeordener 1897, jesuitter 1956, jf. NOU 2013:1, 39-40). Men tilnærmingen var likevel hele tiden at de som tilhørte et annet kirkesamfunn eller en annen religion var å betrakte som avvikere fra det forventede eller normale, nemlig statsreligionen. 
Med trossamfunnsloven fra 1969 ble dette perspektivet imidlertid endret til positiv anerkjennelse av organisert uttrykk for tro. Enhver har ifølge denne loven rett til sammen med andre å danne et trossamfunn så sant rett og moral ikke krenkes (trossamfunnsloven § 1). For å registreres må trossamfunnet oppgi navn, lære og bekjennelse, oppbygning og virksomhet, styremedlemmer og prester/forstandere, og vedtekter om formål, medlemskap og ledelse. Registrerte trossamfunn må også hvert år sende inn en rapport om virksomheten. Bortsett fra at enmannsreligioner ikke er blitt godkjent, er det ikke stilt krav om medlemstall for å bli godkjent, og de innholdsmessige kravene for å bli godkjent og registrert har vært romslige. Begrepet 'trossamfunn' er ikke definert i loven, men i lovforarbeider knyttes det generelt til religiøs tro. Norsk lovkommentar snakker om "troen på en Gud eller krav utenfor en selv. Når denne troen er utformet i et tankemessig system, trosbekjennelse eller lære, som to eller flere personer slutter seg til, kan man snakke om et trossamfunn" (NOU 2013:1, 332-335).

Norsk lov gir imidlertid også livssynssamfunn, det vil si med en sekulær og ikkereligiøs basis, adgang til særskilt statlig anerkjennelse parallelt med trossamfunn, med tilhørende goder og rettigheter. Sekulære livssynssamfunn trenger altså ikke nøye seg med rettslig status som forening (lov om tilskudd til livssynssamfunn 1981, § 1; forskrift om tilskot til livssynssamfunn 1989, § 4). Også her er det krav om at rett og moral ikke krenkes, og at det foreligger opplysninger om hvilket livssyn samfunnet bygger på, i tillegg til generelle organisasjonsopplysninger som virksomhet, utbredelse, føring av medlemsregister. For livssynssamfunn er det imidlertid satt en nedre grense på 500 medlemmer for å kunne få statlig støtte. At det er etablert en slik egen kategori 'livssynssamfunn' i Norge til forskjell fra de fleste andre land må sees i sammenheng med den sterke humanistiske bevegelsen i Norge, Human-etisk forbund, stiftet i 1956 og i dag med ca. 84.000 medlemmer (Statistisk sentralbyrå 2013).

Søknader om godkjenning behandles i statsforvaltningen og byråkratiet, først av fylkesmannsembetet ${ }^{1}$, og deretter blir eventuelle klager behandlet av departementet, p.t. Kulturdepartementet. Til forskjell fra Danmark og flere av de andre nordiske landene er det altså ingen formell representasjon av vitenskapelige fageksperter innen religionsstudier eller teologi i vurderingen av slike saker.

På tross av bestemmelsen om statsreligion har det altså siden tidlig på 1900-tallet i praksis vært individuell og kollektiv religionsfrihet, og siden 1970-tallet dessuten også i tillegg vært hva vi kan kalle korporativ religionsfrihet, med adgang til statlig anerkjennelse og egen rettslig status både for religiøst baserte trossamfunn og for sekulært eller ikke-religiøst baserte livssynssamfunn. Slik sett innebærer opphevelsen av bestemmelsen om statsreligion ingen endring i beskyttelsen av religionsfriheten.

1 Fylke tilsvarer de tidligere danske amter. 


\section{Religionsfrihet og lovgivning}

Et annet aspekt ved grenseflatene mellom stat og tros- og livssynssamfunn er hvordan hensynet til religionsfrihet avveies der religionsutøvelse kommer i konflikt med andre deler av lovverket. Særlig likestillings-, diskriminerings- og arbeidsmiljøområdet har utløst slike konflikter. Her har det nylig (2008) skjedd en innstramning av i hvilke tilfeller lovgivning på disse områdene kan tilsidesettes under hensyn til religionsfrihet. Tidligere hadde trossamfunn enkelt sagt et generelt unntak fra likestillingslovgivning og fra forbud mot diskriminering på grunn av kjønn, religiøs overbevisning eller seksuell orientering, spesielt i arbeidslivet. De kunne for eksempel avvise en søker til en stilling som økonomimedarbeider dersom vedkommende ikke delte deres religiøse overbevisning, eller en søker til en stilling som ungdomsarbeider dersom vedkommende levde i homofilt partnerskap. Nå stilles det strengere betingelser for at trossamfunn ikke skal rammes av lovens forbud. Kravet om unntak må begrunnes med at det er nødvendig for å oppnå et saklig formål og ikke er uforholdsmessig inngripende overfor den som forskjellsbehandles. Der det dreier seg om ansettelser, må kravet til kjønn eller samlivsform ha avgjørende betydning for utøvelsen av arbeid eller yrke (likestillingsloven $\S 3$ pkt.2). I eksemplene ovenfor må trossamfunnene altså begrunne hvorfor religiøs tro er avgjørende for utøvelsen av arbeidet som økonomimedarbeider, eller samlivsforhold for arbeidet som ungdomsarbeider. De må også kunne godtgjøre at en slik forskjellsbehandling ikke er er uforholdsmessig inngripende overfor søkerne. Her har tros- og livssynssamfunnene altså fått mindre frihet, og møter sterkere krav om å følge den alminnelige lovgivningen også der de opplever at denne er i konflikt med den religiøse overbevisning.

\section{Autonomi og statens offentlige religion}

Men et annet spørsmål er om religionsfriheten derimot har vært begrenset innad i statens offentlige religion. Begrepet 'statens offentlige religion' indikerer jo en religion som er integrert i statsapparatet, mangler selvstendige organisatoriske strukturer så vel som selvstendighet i indre anliggender, og der myndighet utøves av statsmaktens lovgivende og utøvende makt. Dette var også tidligere uttrykt i Grunnloven, gjennom bestemmelsen som fastsatte at Kongen "anordner al offentlig Kirkeog Gudstjeneste, alle Møder og Forsamlinger om Religionssager" (tidligere Grunnloven § 16). Det er denne paragrafen som har vært forankringen for Kongen, dvs. regjeringen, som øverste ledelse av kirkeforvaltningen, til forskjell fra Danmark. Kongen avgjorde liturgiske, læremessige og ordningsmessige spørsmål, og utnevnte geistlige embetsmenn på samme måte som militære og sivile embetsmenn (tidligere Grunnloven § 21). Dessuten var Kongens myndighet i kirkelige anliggender mindre begrenset av den lovgivende myndighets kompetanse enn på andre områder. 
Denne enheten mellom stat og religion ble gradvis mer problematisert og utfordret fra slutten av 1800-tallet. Ut over 1900-tallet økte kravet om mer selvstendighet, og som et resultat opprettes det gradvis kirkelige organer med basis i lov, til å uttale seg og opptre på vegne av Den norske kirke: menighetsråd (1920) og bispedømmeråd (1933). I 1984 ble Kirkemøtet opprettet som valgt, kirkelig organ på nasjonalt nivå. Med denne opprettelsen fikk kirken selv delegert myndighet til å avgjøre liturgisaker og vedta nye gudstjenesteordninger, salmebok, strategier og planer for kirkelig virksomhet. Den kunne også bestemme tjenesteordninger for de kirkelige yrkesgruppene $^{2}$ og avgi uttalelser på vegne av Den norske kirke. I 1996 ble det vedtatt en ny kirkelov som gjorde soknet til eget rettssubjekt.

Ved slutten av 1900-tallet hadde Den norske kirke altså både fått egne, lovfestede organer til å opptre på kirkens vegne også på nasjonalt nivå, og oppnådd indre selvstendighet på viktige områder, uten at det var gjort endringer i Grunnlovens bestemmelser. Dette var likevel en begrenset frihet. Dels var kirkens myndighet i stor grad delegert, og ikke overført, og dels ble flere viktige områder fremdeles styrt av departement, minister og regjering. Biskoper og proster ble fremdeles utnevnt av regjeringen, riktignok etter en kirkelig nominasjons- og avstemmingsprosess. Den norske kirke nasjonalt var ikke et eget rettssubjekt, men en del av statsadministrasjonen. Viktige deler av økonomien ble styrt fra departement og gjennom statsbudsjettet.

Rundt år 2000 ble det som nevnt ovenfor tatt både kirkelige og politiske initiativer til igjen å utrede forholdet mellom staten og Den norske kirke, med sikte på mulige endringer av Grunnlovens bestemmelser. En kirkelig utredning foreslo i 2002 å løsrive Den norske kirke fra staten, og på sikt gi den og andre tros- og livssynssamfunn samme posisjon overfor staten, mens et regjeringsoppnevnt utvalg gikk inn for at en selvstendig folkekirke, fristilt fra staten, men fortsatt regulert i en særskilt lov. Men det var ikke støtte til disse forslagene på grunnplanet i Den norske kirke eller rundt om i kommunene, og også blant de politiske partiene var det betydelig uenighet (Schmidt 2007). Samtidig var det en klar forutsetning for regjeringen at det måtte være bred oppslutning om eventuelle endringer.

Det politiske forliket som ble inngått i april 2008 om å endre Grunnlovens bestemmelser om religion fikk dermed mer preg av et pragmatisk kompromiss enn en prinsipiell og konsistent gjennomtenkt nyordning av forholdet mellom stat og kirke. Selv om disse endringene har gitt Den norske kirke større selvstendighet og dermed en tydeligere grenseflate overfor staten og statlige organers styring og intervensjon, er kirkens selvstendighet likevel fremdeles klart begrenset.

Den norske kirke er ennå ikke eget rettssubjekt, men en del av statsadministrasjonen, og prester og biskoper er fremdeles statsansatte. Kirkens sentrale organer som kirkeråd og Kirkemøtet forventer at dette vil endre seg i løpet av de nærmeste årene og forbereder for tiden en slik endring (Kirkerådet 2014, Kirkemøtet 2014). Den

2 Dog med unntak av prestene, der tjenesteordning fortsatt fastsettes av Regjeringen ved kgl. res. 
norske kirkes konfesjonelle identitet som evangelisk-luthersk er fastsatt i Grunnloven, og kan altså ikke endres uten en grunnlovsendring. Det samme er også bestemmelsen som 'Norges folkekirke', men det er mer uklart om og i så fall hvilke rettslige begrensninger av kirkens frihet det følger av dette. Muligens vil lover og ordninger for kirken vurderes opp mot denne bestemmelsen i lys av hvorvidt de innskrenker medlemsrettigheter som det å delta i valg, innad i gruppen av døpte.

Den norske kirkes frihet begrenses også av at "nærmere bestemmelser om Kirkens ordning fastsettes ved Lov" (Grunnloven § 16), altså av Stortinget. Denne bestemmelsen endrer grenseflaten mellom stat og kirke på flere måter. Det er ikke nytt at kirkeordningen fastsettes ved lov, men det er nytt at det grunnlovsfestes at den skal fastsettes slik, og at terskelen dermed heves for å overføre denne kompetansen til kirkelige organer. Hvordan ordning i praksis vil bli bestemt, vil være sentralt for grenseoppgangen mellom Stortingets myndighet sett opp mot kirkens egen normgivingskompetanse, og dermed for grenseflaten mellom stat og kirke (Smith 2012, 114-115). I Stortingsmeldingen der endringsforslagene er utdypet, blir ordning definert som kirkens ytre organisering. Men det poengteres samtidig at Stortingets lovgivningskompetanse går videre når det gjelder Den norske kirke enn når det gjelder de andre tros- og livssynssamfunnene. Den nåværende kirkelov regulerer blant annet kirkelig organisasjon og oppbygning, kirkelige organer og deres formål og oppgaver, og kirkelige valgordninger, altså det som må betegnes som indre forhold i kirken. Et viktig spørsmål når det gjelder grenseflaten mellom stat og kirke, og kirkens autonomi, er dermed om en fremtidig kirkelov vil fortsette å regulere slike forhold. I øyeblikket er det ikke avklart hvor omfattende en ny kirkelov vil bli, men det er ikke opplagt at den ikke vil regulere slik forhold. I tillegg kommer også det moment at den myndighet som utøves av Stortinget i kirkelige anliggender, til forskjell fra den myndighet som tidligere ble utøvd av Konge og regjering, selvsagt ikke underlagt en bekjennelsesforpliktelse. Stortinget kan ikke i noen sammenheng oppfattes som et kirkelig organ.

Statens finansiering av Den norske kirke over statsbudsjett og kommunale budsjetter gir også mulighet til å styre Den norske kirke gjennom budsjettproposisjoner og deres beskrivelse av formål og virksomhet. Dessuten gir den mulighet til å styre gjennom de prinsipper som generelt regulerer styring og forvaltning av offentlig bevilgede midler, som krav til målfastsettelse og rapportering av resultatoppnåelse. Styringsmuligheten er mindre for tros- og livssynssamfunnene, som jo er berettiget til statlig og kommunal støtte på samme nivå som Den norske kirke, regnet ut fra medlemstall. Innimellom dukker likevel spørsmålet opp om hvorvidt den offentlige støtten samtidig også rettferdiggjør visse forventninger til at trossamfunnenes praksis og lære ikke er i konflikt med grunnleggende samfunnsverdier. Foreløpig er dette ikke blitt satt på spissen. Men et regjeringsoppnevnt utvalg til å utrede en helhetlig tros- og livssynspolitikk har fremsatt konkrete forslag 
om dette, blant annet at styrende organer i trossamfunn som forvalter offentlige tilskudd skal være tilgjengelige for begge kjønn (NOU 2013:1, 338-350).

Selv om en sentral tendens i de pågående endringene er at Den norske kirke i større grad selvstendiggjøres fra staten, står den ikke alene. Noen elementer i statens styre av Den norske kirke videreføres, og på enkelte punkter forsterkes også statens mulighet til å intervenere, ikke bare i Den norske kirke, men også i tros- og livssynssamfunn. Påstanden om at stat-kirke-forhold entydig går fra statlig styring til statlig støtte av mer selvstendige og fristilte majoritetskirke og trossamfunn må altså nyanseres betydelig, dersom vi ser på Norge.

\section{Likebehandling og religionsmodellens grenseflater}

Spørsmålet om like- kontra forskjellsbehandling i religionsmodellen aktualiseres på ulike måter: med henblikk på økonomi og ressurser, med henblikk på lovregulering og fordeling av plikter og rettigheter, og med henblikk på symbolske dimensjoner.

Når det gjelder økonomi er Den norske kirke og tros- og livssynssamfunnene langt på vei likestilt. Den norske kirke finansieres stort sett i sin helhet av stat og kommuner, gjennom bevilgninger over statsbudsjettet og de kommunale budsjettene. Det er hverken kirkeskatt eller medlemsavgift. Tros- og livssynssamfunnene er berettiget til tilskudd fra statskassen og fra kommunene der det bor medlemmer av tros- eller livssynssamfunnet, proporsjonalt med bevilgningene til Den norske kirke, beregnet pr. medlem. Modellen er basert på prinsippet om at dersom staten støtter Den norske kirke økonomisk, ja så følger det at den også bør støtte andre tros- og livssynssamfunn tilsvarende. For tros- og livssynssamfunn har dette prinsippet vært lovfestet siden 1969, for livssynssamfunnenes vedkommende siden 1981. Det er noen begrensninger i likebehandlingen. Den tydeligste forskjellen er at livssynssamfunn må ha minst 500 medlemmer for å få slikt tilskudd, mens det ikke er noe krav til medlemstall i trossamfunn. I tillegg har det vært stilt spørsmål til beregningsgrunnlaget for utregning av tilskuddet til tros- og livssynssamfunnene. Mer grunnleggende har det vært pekt på at selve ordningen er asymmetrisk, ved at den tar utgangspunkt i bevilgninger til Den norske kirke og behandler tilskudd til trosog livssynssamfunn som avledet av denne mer opprinnelige forpliktelsen.

Like- eller forskjellsbehandling aktualiseres på flere steder når det gjelder fordeling av rettigheter og plikter: I Norge er kalender og offentlige fridager hovedsakelig basert på Den norske kirkes helligdager. Personer som ikke tilhører Den norske kirke har rett til inntil to fridager $\mathrm{i}$ forbindelse med egen religions høytider og helligdager, men arbeidsgiver kan kreve at disse dagene arbeides inn igjen. Ordinerte prester i Den norske kirke har automatisk vigselsrett i kraft av sin ordinasjon og kan dermed foreta den sivilrettslige delen av ekteskapsinngåelse. Prest eller forstander i registrert tros- eller livssynssamfunn kan med godkjennelse av fylkesmannen også foreta vigsler, dersom vigselsritualet er godkjent av departemen- 
tet. Norge vedtok kjønnsnøytral ekteskapslov i 2009, men vigslere fra tros- eller livssynssamfunn har likevel rett til å nekte å vie to av samme kjønn. Soknene i Den norske kirke eier de offentlige gravplassene, kirkegårdene, og er ansvarlige for forvaltning og vedlikehold, men kommunene dekker utgiftene til dette. Enhver har rett til å bli gravlagt på offentlige gravplass, og med respekt for sitt religion eller livssyn. Registrerte trossamfunn kan få tillatelse til å anlegge egen gravplass, og ved innvielse av ny gravplass skal tros- og livssynssamfunn gis anledning til å gjennomføre en seremoni. Det som går igjen er altså at Den norske kirke på ulike måter har en privilegert posisjon og settes i en særstilling, samtidig som man forsøker å ivareta hensyn til tros- og livssynssamfunnene. Denne særstillingen kan imidlertid ikke sees som utslag av Grunnlovens bestemmelser om forholdet mellom staten og Den norske kirke, men bør heller forstås som resultat av Den norske kirkes generelle stilling i kultur og samfunn. Blant annet er det uttrykkelig slått fast i en høyesterettsdom at bestemmelsen om statsreligion ikke binder den lovgivende myndighet $\mathrm{i}$ andre saker enn dem der staten er kirkestyre (Børre Knudsen-dommen 1983, jf. NOU 2006: 2, 41).

Det er gjerne blitt hevdet om den norske Grunnloven at dens betydning like mye er knyttet til dens symbolfunksjon som til dens betydning som rettslig dokument (jf. Nordby 2002). Den er bærer av mening, for eksempel forestillinger om statsdannelsen og nasjonen, og hvordan de binder borgere og innbygger sammen i et fellesskap, like mye som den er et sett med rettslige bestemmelser angående statsmakten. Det er verdt å overveie om en slik symbolfunksjon også er fruktbar for å forstå betydningen av enkeltbestemmelser i Grunnloven. Leses bestemmelsen om statens offentlige religion i dette lyset, er ikke poenget først og fremst rettslige implikasjoner av bestemmelsen. Oppmerksomheten rettes i stedet mot hvordan preferansen for én fremfor andre religioner er med på å vedlikeholde en særskilt forbindelse mellom staten og dens underliggende mening og betydning, og religionen, det vil si Den norske kirke. Den gir en bestemt religion en særlig plass og posisjon i statsdannelsen, ikke nødvendigvis i rettslig forstand eller med tanke på ressursfordeling og -tilgang, men gjennom å formidle et bilde av og en forestilling om staten og dens dypere mening, formål og sammenheng som knyttet til en særlig religion. I denne sammenhengen er det også verdt å legge merke til at en bestemmelse som ikke ble endret, er bestemmelsen om at "Kongen skal alltid bekjenne seg til den evangelisk-lutherske religion", med andre ord være medlem av Den norske kirke (Grunnloven § 4). Tidligere hang dette selvsagt sammen med at Kongen jo var kirkens øverste leder, men dette er jo nå endret. Dermed er det snarere forbindelseslinjen mellom Den norske kirke og Kongen som nasjonalt symbol og overhode som står igjen.

I den nye religionsbestemmelsen i Grunnloven defineres ikke Den norske kirke lenger som 'statsreligion', men som 'Norges folkekirke' (Grunnloven $\S 16$ ), opplagt inspirert av den danske grunnlovens § 4 (Grundloven § 4), med røtter tilbake til 1849. Som nevnt ovenfor er det vanskelig å peke på hva de konkrete og rettslige implikasjonene av denne bestemmelsen skulle være, ut over at de forplikter staten til 
å yte støtte i et visst omfang til både Den norske kirke og de øvrige tros- og livssynssamfunnene. Men den er samtidig heller ikke bare en ren konstatering av et saksforhold, f. eks. av befolkningsandelen som er medlemmer av Den norske kirke. Det er vanskelig ikke å lese denne formuleringen som en bekreftelse og anbefaling av Den norske kirkes særlige plass i befolkning og nasjon. Denne særstillingen holdes ikke primært ved like gjennom rettslige prinsipper eller gjennom prioritering i ressursfordeling, men gjennom å skape og gjenskape assosiasjoner om forbindelsene mellom folk og nasjon, og Den norske kirke. Dermed er den med på å poengtere og understreke forskjeller mellom tros- og livssynssamfunn generelt, og Den norske kirke spesielt.

Slik sett kan dette se ut som en bekreftelse av påstandene om de nordiske landenes endringer av stat - kirke-relasjoner, nemlig at de kutter de særlige båndene mellom stat og majoritetskirker, men beholder og styrker de særlige båndene mellom nasjon/folk, og folkekirke. Men et ytterligere poeng er at staten og statsmakten gjennom Grunnloven og dens bestemmelser er aktivt involvert i å bygge opp om og vedlikeholde disse forestillingene. Dette er ikke en særstilling som bare eksisterer og vedlikeholdes gjennom Den norske kirkes plass i landets tradisjon, kultur og historie. Det er også en særstilling som den lovgivende statsmakten er med på å bygge opp under gjennom å innskrive den i Grunnloven.

\section{Religionsmodellens grenseflater konkret: Religion og sykehus}

Så langt har vi sett på hvordan grenseflater formes og omformes på et overordnet nivå, gjennom bestemmelser i Grunnloven og andre deler av lovverket. Men viser de seg på samme måten når religion og stat møtes i mer lokale og konkrete praksiser? I det følgende skal vi se på hvordan grenseflatene viser seg innen statlige institusjoner, nærmere bestemt i tilknytning til religiøs betjening i sykehus.

I Norge har spesialisthelsetjenesten siden 2001 vært organisert etter den såkalte helseforetaksmodellen. Offentlige sykehus er statlig eid via fire regionale helseforetak, med egne styrer og et desentralisert, selvstendig ansvar for å styre foretaket i samsvar med overordnede mål og ressurstildelinger. Det er ikke fastsatt særskilte lover eller regler for religionsutøvelse i sykehus, ut over den generelle religionsfriheten og et overordnet formål i pasientrettighetsloven som sier at loven skal "ivareta respekten for den enkelte pasients og brukers liv, integritet og menneskeverd" (Pasient- og brukerrettighetsloven $\S 1-1$ ). Det er dermed opp til det enkelte sykehus selv å avgjøre hvordan man vil legge til rette for religiøse tjenester, aktiviteter og praksiser.

Offentlige og private, diakonale sykehus har ordninger for tilgang til religiøs betjening, men ikke nødvendigvis privateide, kommersielle sykehus. Ved de aller fleste av de offentlige og de private diakonale sykehusene er det ansatt egne sykehusprester. Disse er ansatt og finansiert av det enkelte sykehuset. Der det ikke er 
egen sykehusprest ansatt, er det en tilkallingsordning. De siste tyve årene har det vært en økning i antall ansatte sykehusprester på ca. 40 prosent, en økning som omtrent tilsvarer økningen i antall innleggelser.

Ansatte sykehusprester har stort sett utelukkende vært prester ordinert i og tilhørende Den norske kirke, og under tilsyn av biskop i Den norske kirke. I utlysninger stilles det ofte eksplisitt krav om at kandidater i tillegg til å ha pastoralklinisk utdanning skal være ordinerte prester i Den norske kirke, eller tilfredsstille kravene for dette. Det betyr teologisk embetseksamen, i tillegg til å tilhøre enten Den norske kirke, eller et kirkesamfunn som har økumenisk avtale med Den norske kirke. I praksis vil det si Metodistkirken og Den evangelisk-lutherske frikirke, men også de nordiske folkekirkene, og kirkene i Porvoo-fellesskapet. Dominansen i sykehusene av prester tilhørende Den norske kirke kan altså ikke bare sees som et uttrykk for Den norske kirkes tallmessige dominans og at det typisk vil være prester som er ordinert i denne som også møter stillingsmessige kvalifikasjoner som pastoral-klinisk utdanning. Det kan også avspeile en eksplisitt og tilsiktet prioritering fra sykehusenes side.

De seneste årene har det vært en viss endring. I 2008 ble en pinsevenn ansatt som sykehusprest ved et av sykehusene i Oslo-området. Siden 2009 har St. Olavs hospital $\mathrm{i}$ Trondheim hatt tilsatt en kulturkonsulent $\mathrm{i}$ en deltids prosjektstilling. Vedkommende er muslim, har bakgrunn fra det muslimske samfunnet i Trondheim, og presenteres som et tilbud til innvandrere og fremmedspråklige blant annet om ritualer ved islamsk tro, om samtale for sorg, krise og eksistensielle spørsmål, og om åndelige spørsmål knyttet til islamsk tro. Dessuten tilbyr han undervisning overfor ansatte om kulturtradisjoner, kulturforståelse og kommunikasjon med innvandrere, og samtale med ansatte med innvandrerbakgrunn. Han formidler også kontakt med andre tros- og livssynssamfunn.

Ved Oslo universitetssykehus ble det i 2011 startet et pilotprosjekt for tros- og livssynsbetjening for pasienter og pårørende på sykehus, med formål å sikre likebehandling av alle pasienter i tråd med religionsfrihet som menneskerettighet. Prosjektet skulle etablere, kurse og følge opp et ressursteam for tro- og livssynsbetjening. Dette ressursteamet består i 2012 av 20 personer fra ulike tros- og livssynssamfunn, organisert i en tilkallingsordning, og honorert via prosjektmidler fra Kulturdepartementet, Barne-, likestillings- og integreringsdepartementet og Helse Sør-Øst RHF. Dette ressursteamet er nå også tilgjengelig for flere andre sykehus i Oslo-regionen. I tillegg har den katolske kirke i Oslo tilsatt to prester som skal betjene sykehusene i Østlandsområdet; den ene av disse skal i tillegg også betjene fengsler. For øvrig er tilgang til religiøs betjening for dem som ikke ønsker å benytte seg av sykehusprestene basert på at sykehuset formidler kontakt med personer fra andre tros- eller livssynssamfunn.

Generelt presenterer sykehusprestene seg som et tilbud om samtale og støtte for pasienter og pårørende i forbindelse med opplevelser av krise, sorg, eksistensielle 
eller relasjonelle utfordringer eller andre sider ved livssituasjonen som aktualiseres av sykdom og sykehusopphold. Det nevnes kanskje at presten er et tilbud om livshjelp, nærvær og trøst i krise, eller veiledning i eksistensielle eller åndelige spørsmål. I tillegg til samtale tilbyr prestene også ritualer og seremonier, men heller ikke her sies det nødvendigvis noe om hvorvidt dette er spesifikt knyttet til ritualer i Den norske kirke eller kirke overhodet, ut over der spesifikt kirkelige ritualer som dåp og nattverd nevnes spesifikt. Det sies eksplisitt at sykehusprestene kan hjelpe pasienter og pårørende. Et eksempel, som med noen variasjoner er ganske representativt for måten prestenes tjenester presenteres på, finner vi på hjemmesiden til St. Olavs hospital:

Sykehusopphold utløser ofte behov for samtale og personlig nærvær. Det kan dreie seg om relasjonene til ens nærmeste eller om livssituasjonen totalt sett. Mange har behov for å snakke med noen om sine håp, sin frykt eller om spørsmål som angår tro og livssyn. Prestene er utdannet til å være samtalepartnere, og kan møte det enkelte menneske med støtte, veiledning eller sjelesorg, eller bare være til stede og dele stillheten. Samtalen vil alltid foregå på premissene til den som søker kontakt. Enhver har rett til å få snakke med en prest, og kan be personalet kontakte prestetjenesten eller ta kontakt selv. Ofte mangler vi egne ord for å uttrykke viktige hendelser eller følelser. Ritualene er da en god hjelp. Det dreier seg om avskjeds- og minnestunder, nøddåp og nødvigsel, nattverd, forbønn, velsignelseshandlinger. Mange ritualer blir til ut fra den aktuelle situasjonen. Andre er kjent fra en lang kirkelig tradisjon (St. Olavs hospital 2013).

Det sies stort sett alltid at prestene også er behjelpelige med å formidle kontakt med representanter for andre tros- eller livssynssamfunn, der pasienter eller pårørende ønsker det.

I tillegg til disse tjenestene overfor pasienter og pårørende nevnes det også gjerne hvordan prestene bistår faggrupper og ansatte ved sykehuset med samtale, veiledning og undervisning, eksempelvis i emner som sorg og krise, eller etikk. Det er dessuten vanlig, uten at dette nødvendigvis er nevnt i presentasjonen utad, at sykehusprest er medlem av den klinisk-etiske komiteen som ethvert sykehus er pålagt å ha. Sykehusprestene presenteres og presenterer seg selv i stor grad som et tilbud til alle, uavhengig av tro og livssyn. Enkelte steder sies dette eksplisitt, som ved Oslo universitetssykehus: Sykehusprestene har solid kompetanse som sjelesørgere og samtalepartnere og er ansatt for å kunne hjelpe når livet blir krevende - uansett religion og livssyn. Samtidig formidler vi gjerne kontakt med representant for andre tros- og livssyn om det er ønskelig (Oslo universitetssykehus 2013).

De fleste steder er det underforstått ved at prestetjenesten ikke fremstår som forankret i en bestemt kirke eller særlig innrettet mot dem som tilhører en bestemt kirke eller religion. 
Disse korte observasjonene kan utfylle bildet av grenseflatene i en norsk religionsmodell og hvordan de viser seg der stat og religion møtes. Prestene som er ansatt i - og av - sykehuset, kommer stort sett utelukkende fra Den norske kirke. De er en integrert del av sykehuset, og samarbeider også med øvrig helsepersonell, noen ganger fast representert på tverrfaglige møter eller i ulike faglige utvalg, andre ganger mer fra sak til sak. Personer fra andre tros- eller livssynssamfunn kommer inn utenfra, enten som en del av et organisert, opplært og veiledet ressursteam som også helseforetaket har et medansvar for, eller som del av en tilkallingsordning fra troseller livssynssamfunnene. Mens sykehusprestene presenteres som et tilbud relativt uavhengig av en spesifikk religion eller religiøs institusjon, og derfor i utgangspunktet som et tilbud til alle, så fremstår tilkalte personer fra tros- og livssynssamfunnene primært som et tilbud for pasienter og pårørende med tilknytning til disse tros- eller livssynssamfunnene, som et tydelig tros- eller livssynsforankret tilbud.

Når det gjelder betjening fra tros- og livssynssamfunnene er det altså en ganske klar grenseflate opp mot institusjonen, sykehuset, en grenseflate som kan knyttes til en tradisjonell forståelse av differensiering i autonome funksjonssystemer, der religion er et eget funksjons- og kommunikasjonssystem atskilt fra andre, som for eksempel helse og medisin-vitenskap. Sykehusprestene presenteres derimot som formidlere og brobyggere over denne grenseflaten, mellom tros- og livssynssamfunnene og inn i sykehuset.

Når det gjelder de ansatte sykehusprestene er derimot grenseflaten overfor institusjonen langt mindre tydelig. Tjenestene de yter beskrives som i utgangspunktet tjenester for alle, enten det er pasienter, pårørende eller ansatte. Dessuten er en vesentlig del av begrunnelsen for dem forankret i sykehusets overordnede formål: dekke pasienters og pårørendes behov med tanke på å sikre best mulig behandling gjennom tilbud om samtale og støtte, men også å undervise og veilede personale. Dette står ved siden av tjenester som er mer spesifikt forankret i religion og religionsutøvelse, som gudstjenestefeiring, nattverd og dåp. Denne tilordningen av prestetjenesten til sykehusets overordnede formål kan selvsagt sees i sammenheng med at prestene er ansatt og betalt av sykehuset, de er sykehusets personell. Dermed må de også kunne innordnes i den logikk og rasjonalitet som rår i velferdsstatens helse- og omsorgsvirksomhet.

Både i Grunnloven og annet lovverk, og i sykehusene, setter religionssystemets interaksjon med staten institusjonaliserte avtrykk. Men grenseflatene viser seg ikke på samme måte i Grunnloven og den grunnleggende lovgivningen, som på helseområdet. Endringer i lovverkets beskrivelse av forholdet mellom stat og religion generelt, og statens forhold til Den norske kirke spesielt, går alt i alt i retning av en tydeligere grense mellom stat og kirke. Den norske kirke går fra å være en del av statsapparatet, riktignok med betydelig selvstendighet, til å bli en mer selvstendig folkekirke, men fortsatt med en statlig fastsatt, symbolsk særstilling i samfunn og 
befolkning, sammenlignet med tros- og livssynssamfunnene. I de statlige sykehusene er det en svært tydelig grenseflate mellom tros- og livssynssamfunnene og sykehuset hva angår religiøs betjening, mens de ansatte prestene, som samtidig er Den norske kirkes prester, er sterkt integrert og nærmest uten grenseflate opp mot sykehuset.

\section{Religionsmodell og grenseflater i offentlig religion}

Denne forskjellen mellom hvordan religionsmodellens grenseflater viser seg i lovgivning og innen helsesektor og sykehus illustrerer et mer overordnet poeng, nemlig at en religionsmodell og dens grenseflater varierer mellom ulike sektorer eller domener av offentligheten. Grenseflatene i en norsk religionsmodell er ikke ensartede og sammenfallende i ulike samfunnssektorer, og de endrer seg ikke nødvendigvis på samme måte.

Linda Woodheads utkast til en omvurdering og revidert teoretisk tilnærming til offentlig religion kan være fruktbar for å utdype disse observasjonene nærmere. Woodhead tar utgangspunkt $\mathrm{i}$ en påstand om at to tradisjonelle teorier har vist seg utilstrekkelige til å beskrive og forstå offentlig religion i et endret religiøst landskap. Den tradisjonelle og velkjente inndelingen i offentlig og privat som plasserer religionen i det private rommet, er ute av stand til å artikulere hvordan religion i samtiden er tilstede og virksom i offentlige sfærer. I sin bok fra 1994 om offentlig religion i den moderne verden har i stedet tatt til orde for en tredeling av offentligheten i stat, politikk og sivilsamfunn. Hans påstand er at religionen riktignok har vendt tilbake til offentligheten, men da først og fremst i betydningen av sivilsamfunnet, og klart atskilt fra staten (Casanova 1994, 218-219). Også denne modellen baserer seg på at differensiering i funksjonelle systemer som rett, økonomi, kunst, vitenskap, som vedlikeholdes gjennom selvrefererende kommunikasjonsformer, er et ufrakommelig trekk ved moderniteten. Følgen er at det er vanskelig å uttrykke hvordan religion kan være en faktor som er til stede og gjør seg gjeldende innen andre systemer, som for eksempel vitenskap eller helse (Woodhead 2012, 13; jf. Casanova 1994, 212).

Et stort problem ved disse modellene, ifølge Woodhead, er at de tar differensiering i klart atskilte funksjonssystemer for gitt. Den tredelte modellen er dessuten for knyttet til en amerikansk kontekst der stat og sivilsamfunn relativt klart atskilt fra hverandre til å kunne belyse offentlig religion der dette skillet er mindre klart. Det er det blant annet i en del europeiske land, ikke minst i de nordiske velferdsstatene.

Woodhead fremsetter i stedet et utkast til en alternativ og mer kompleks modell for å redegjøre for offentlig religion og måten religion agerer i offentlige sfærer på. Denne modellen tar for det første utgangspunkt i ideen om sosial differensiering og hvordan ulike samfunnsområder er differensiert fra hverandre, men - og det er det viktige - ikke som skarpt avgrensede områder der kommunikasjonsformer innen ett område ikke kan virke inn i et annet. Tvert imot er grensene mellom disse områdene 
porøse, uklare og skiftende. Mulige områder kan for eksempel være økonomi, politikk, utdannelse, rett og jus, helse, statlig og ikke statlig vold/tvang, fritid, media, velferd (Woodhead 2012, 14).

For det andre regner den med at forholdet mellom stat og sivilsamfunn, og statens tilstedeværelse, utspiller seg på ulike måter i de ulike områdene. I denne modellen fremstår offentlig religion ikke som ett område atskilt fra de øvrige, men i stedet som en faktor eller kraft som gjør seg gjeldende innen ulike samfunnsområder. Et viktig poeng er for det første at det gjør den på ulike måter innen de ulike områdene. Religion kan være tilstede og virksom på en måte i helseområdet, på en annen innen utdanningssektoren, og på en tredje innen lovgivning. Siden staten også vil være aktivt involvert i disse områdene på ulike måter sier det seg selv at interaksjonen mellom religion og stat vil arte seg ulikt. Det er nettopp det som er tilfellet når grenseflatene i religionsmodellen manifesterer seg på én måte i lovgivning, og en annen måte i helsesektoren og sykehus.

For det tredje poengterer Woodhead hvordan en sakssvarende forståelse av hvordan religion utfolder seg i offentlige sfærer, også må ta høyde for at ulike former for religion kan gjøre seg gjeldende på ulike måter innen et område, og at de kan samarbeide eller stå i et konkurranseforhold. Dette så vi tydelig illustrert innen helseområdet. Religion innen helseområdet i Norge er to helt forskjellige ting avhengig av om vi ser på Den norske kirke, eller vi ser på de andre tros- og livssynssamfunnene, samtidig som det ser ut til at dette fostrer samarbeid snarere enn konkurranse. Nettopp ved å arbeide med grenseflater i religionsmodellen kommer slike forskjeller tydelig frem.

Et fjerde relevant moment i Woodheads reformulering av offentlig religion er at den må ta høyde for det religiøses og det sekulæres gjensidige plassering og relative makt på ulike områder. Forholdet mellom religion og sekularitet er ikke et stabilt, en gang for alle gitt forhold i offentlige sfærer. Det utspiller seg, formes og omformes på ulike måter i ulike områder. Når det gjelder religion innen helseområdet slik vi analyserte det ovenfor, har en relativt sekulær helse- og omsorgsvitenskap og -profesjon i ganske stor grad også farget den ansatte og integrerte religiøse betjeningen. Den markante tilstedeværelsen av religion i form av prester ansatt og betalt ved så godt som alle sykehus, henger tett sammen med tilpasningen mellom det språket og den logikken som bestemmer sykehus- og helseområdet, og den som prestetjenesten artikuleres gjennom. Samtidig er også en annen logikk på vei inn, om enn ennå i svært begrenset grad, nemlig en menneskerettsorientert religionsfrihetslogikk, der religion nettopp vil betone uavhengighet av og frihet fra statlig definerte logikker og språk.

\section{LITTERATUR}

Casanova, José

1994 Public Religions in the Modern World, The University of Chicago Press, Chicago and London. 
Christoffersen, Lisbet et al., eds.

2012 "Den danske religionsmodel" in: idem. Fremtidens danske religionsmodel, Forlaget Anis, København, $13-22$.

Diskrimineringsloven

2005 Lov om forbud mot diskriminering på grunn av etnisitet, religion mv., 2005, sist endret 2013.

Doe, Norman

2011 Law and Religion in Europe. A Comparative Introduction, Oxford University Press, Oxford.

Grundloven

1953 Danmarks Riges Grundlov, nr 169 af 5. juni 1953.

Ferrari, Silvio

2010 "Introduction to European Church and State Discourses" in: Lisbet Christoffersen, Kjell Å Modéer \& Svend Andersen, eds., Law \& Religion in the $21^{\text {st }}$ Century - Nordic Perspectives, DJØF Publishing, København, 23-41.

Forskr. om tilskot til livssynssamfunn

1989 Forskrift om tilskot til livssynssamfunn, 1989.

Fox, Jonathan

2008 A World Survey of Religion and the State, Cambridge University Press, Cambridge.

Grunnloven

1814 Kongeriget Norges Grundlov, given i Rigsforsamlingen paa Eidsvold den 17de Mai 1814 (med senere endringer).

Kirkemøtet

2014 KM 13/14 Etablering av arbeidsgiveransvar. Merknader fra kirkemøtekomiteen og Kirkemøtets vedtak, http://www.kirken.no/?event=doLink\&famID=389154 (sett april 2014).

Kirkerådet

2014 Årsrapport for de sentralkirkelige råd, http://www.kirken.no/?event=showMeetingPlan\&famID=8465 (sett april 2014)

Likestillingsloven

2013 Lov om likestilling mellom kjønnene, 2013.

Lov om tilskudd til livssynssamfunn

1981 Lov om tilskott til livssynssamfunn, 1981, sist endret 2004.

Neuberger, Benyamin

2012 "Cooperation between church and state in liberal democracies" in: Jonathan Fox, ed., Religion, Politics, Society \& the State, Oxford University Press, Oxford, 11-26.

Nielsen, Marie Vejrup

2012 "Kirkelig autonomi i de nordiske lande", in: Lisbet Christoffersen et al., eds., Fremtidens danske religionsmodel, Forlaget Anis, København, 41-54.

Nordby, Trond

2002 "Norges grunnlov, fra styringsredskap til symbol - samt noen tanker om å gjenreise redskapsfunksjonen", Tidsskrift for samfunnsforskning 43 (4), 481-506.

NOU

2006 NOU 2006:2 Staten og Den norske kirke, Kultur- og kirkedepartementet, Oslo.

2013 NOU 2013:1 Det livssynsåpne samfunn. En helhetlig tros- og livssynspolitikk, Kulturdepartementet, Oslo.

Oslo universitetssykehus

2013 Sykehusprestene ved Oslo universitetssykehus, http://www.oslo-universitetssykehus.no/omoss/ avdelinger/prest/Sider/enhet.aspx (sett des. 2013).

Pasient- og brukerrettighetsloven

1999 Lov om pasient-og brukerrettigheter. 
Schmidt, Ulla

2007 Oppsummering av høringssvarene. NOU 2006:2 Staten og Den norske kirke, KIFO notat nr. 2/2007, Stiftelsen kirkeforskning, Oslo.

Smith, Eivind

2012 Norge som sekulær stat: Et konstitusjonelt perspektiv, in: Bangstad, Sindre, Oddbjørn Leirvik \& Ingvill Thorson Plesner eds., Sekularisme - med norske briller. Unipub, Oslo, 99-120.

St.Olavs hospital

2013 Prestetjenesten, http://www.stolav.no/no/Omoss/Organisering/Stabsavdelinger/Organisasjon/Prestetjenesten/102285/ (sett des. 2013).

Statistisk sentralbyrå

2013 “Trus- og livssynssamfunn utanfor Den norske kyrkja, 1. januar 2013", http://www.ssb.no/kultur-ogfritid/statistikker/trosamf (sett des. 2013).

Trossamfunnsloven

1969 Lov om trudomssamfunn og ymist anna, 1969, sist endret 2011.

Woodhead, Linda

2012 “Omvärdering av offentliga religion - i skuggan af sekulariseringsteorin". Religionsvidenskabeligt Tidsskrift 58, 5-20.

Ulla Schmidt, professor (mso), dr.theol. Institut for Kultur og Samfund, Aarhus Universitet 